\title{
SUATU STUDI LITERATUR: AKTIVITAS ANTIDIABETIC DARI KULIT JERUK (Citrus sp.)
}

\author{
Maya Sari Mutia ${ }^{1}$, Chrismis Novalinda Ginting ${ }^{2}$, OK Yulizal $^{3}$ \\ ${ }^{1}$ Program Studi S3 Ilmu Kedokteran, Fakultas Kedokteran, Universitas Prima Indonesia, Medan \\ ${ }^{2,3}$ Fakultas Kedokteran, Universitas Prima Indonesia, Medan \\ Email : mayasarimutia11@gmail.com,chrismis@unprimdn.ac.id*,yulizal.tech@gmail.com
}

\begin{abstract}
Diabetes mellitus is a chronic metabolic disease, which is not able to secrete insulin in sufficient quantities or the body is unable to use insulin effectively so there is an excess glucose level and immediately suffer from some complications against the organs. Diabetes mellitus can be cured by herb utility which are thought to have compounds that has an antidiabetic effect. Therefore, this literature study discusses the antidiabetic activity of orange peel (Citrus sp.). The literature search was carried out on the Google Scholar search engine which used some keyword included antidiabetic, extract, orange peel, Citrus. In this literature study, there are inclusion and exclusion criteria for selecting journals as literature sources. The results of 12 literatures review that orange peel had antidiabetic activity by decrease blood glucose levels in some animal trials that had received an effective dose of orange peel extract in each of the reviewed studies. Hence, it can be concluded that various type of Citrus peels has antidiabetic effect.
\end{abstract}

Keywords: Antidiabetic, citrus, orange peel, diabetes

\section{PENDAHULUAN}

Diabetes mellitus merupakan penyakit metabolik yang berlangsung kronik dimana penderita diabetes tidak bisa memproduksi insulin dalam jumlah yang cukup atau tubuh tidak mampu menggunakan insulin secara efektif sehingga terjadilah kelebihan gula di dalam darah dan baru dirasakan setelah terjadi komplikasi lanjut pada organ tubuh (Khairani, 2014).

Prevalensi DM tipe 2 pada bangsa kulit putih berkisar antara 3\%-6\% dari jumlah penduduk dewasanya. Di Singapura, frekuensi diabetes meningkat cepat dalam 10 tahun terakhir. Di Amerika Serikat, penderita diabetes meningkat dari 6.536 .163 jiwa di tahun 1990 menjadi 20.676.427 jiwa di tahun 2010. Di Indonesia, kekerapan diabetes berkisar antara 1.4\%-1.6\%, kecuali di beberapa tempat yaitu di Pekajangan 2.3\% dan di Manado 6\% (Ndraha, 2014)

Laporan hasil Riset Kesehatan Dasar (Riskesdas) tahun 2007 oleh Departemen Kesehatan, menunjukkan bahwa rata-rata prevalensi DM di daerah urban untuk usia di atas 15 tahun sebesar $5.7 \%$. Prevalensi terkecil terdapat di Propinsi Papua sebesar 1.7\%, dan terbesar di Propinsi Maluku Utara dan Kalimantan Barat yang mencapai $11.1 \%$. Sedangkan prevalensi toleransi glukosa terganggu (TGT), berkisar 
antara 4.0\% di Propinsi Jambi sampai $21.8 \%$ di Propinsi Papua Barat dengan rerata sebesar $10.2 \%$ (Soelistijo et al., 2015).

Indonesia diprediksi akan mengalami peningkatan prevalensi diabetes melitus dari 8,4 juta pada tahun 2000 menjadi 14 juta diabetisi pada tahun 2006, dan akan meningkat menjadi sekitar 21,3 juta diabetisi pada tahun 2030. Hal ini akan menjadikan Indonesia menempati urutan ke empat dunia setelah Amerika Serikat, China, dan India dalam masalah diabetes (Handayani \& Muhtadi, 2013)

Diabetes mellitus dapat disembuhkan dengan penggunaan tumbuhan obat yang diperkirakan memiliki senyawa-senyawa yang berkhasiat sebagai antidiabetes mellitus. Penggunaan obat tradisional secara umum dinilai lebih aman dari pada penggunaan obat modern. Hal ini disebabkan karena obat tradisional memiliki efek samping yang relatif lebih sedikit dari pada obat modern (Sinata \& Arifin, 2016)

Kulit jeruk jeruk Sunkist (Citrus sinensis L. Osbeck) telah banyak diteliti efek-efek farmakologisnya, salah satu diantaranya efek anti-hiperglikemik. Ekstrak etanol kulit jeruk Sunkist telah terbukti memiliki khasiat antihiperglikemik baik secara in vitro maupun in vivo baik pada tikus maupun mencit (Esmail Al-Snafi et al., 2019; Luka et al., 2017; Muhtadi et al., 2015).
Manfaat farmakologis tersebut berkaitan dengan berbagai kandungan fitokimia seperti alkaloid, flavonoid, polifenol, fenol, steroid, glikosida, dan saponin dari kulit jeruk Sunkist (Kumar \& Bhaskar, 2015). Oleh karena itu, studi literatur ini membahas secara intens tentang aktivitas antidiabetic dari kulit jeruk (Citrus sp.).

\section{METODE}

Studi literatur ini dilakukan sesuai dengan metode studi literatur yang pernah dilakukan oleh Sujana et al. (2019) dan Yu et al. (2017). Seluruh data dalam penelitian ini merupakan data yang telah dipublikasikan dalam penelitian sebelumnya dengan mencantumkan pengutipan tidak langsung, sehingga tidak diperlukan informed consent dari pasien maupun keterangan layak etik (Sujana et al., 2017; Yu et al., 2018).

Pencarian literature dilakukan pada mesin pencari (search engine) google scholar dengan kata kunci antidiabetic, ekstrak, kulit jeruk, Citrus. Pada studi literatur ini terdapat kriteria inklusi dan eksklusi untuk memilih jurnal sebagai sumber literatur. Kriteria inklusi dalam penelitian ini adalah seluruh jurnal penelitian (research journal) yang dipublish antara 20162021 dan jurnal yang dapat diakses gratis (free full text journal). Sementara 
itu, kriteria eksklusi berupa jurnal yang tidak termasuk jurnal penelitian (research journal) dan dipublish sebelum 2016.

Dalam studi literatur ini terdapat 12 jurnal yang direview dalam studi literatur ini. Dari 12 jurnal yang direview, sebanayk 6 jurnal dipublikasi dalam Bahasa Indonesia dan 6 jurnal lainnya dipublikasi dalam Bahasa Indonesia. Masing-masing jurnal dievaluasi dosis efektif, jenis jeruk yang digunakan, dan metode yang digunakan untuk mengevaluai manfaat antidiabetik.

\section{HASIL DAN PEMBAHASAN}

Pada beberapa penelitian dilakukan pembuktian aktivitas antidiabetes pada kulit jeruk dengan menggunakan hewan percobaan yang diinduksi sehingga menjadikan tikus diabetes. Induksi hewan percobaan dilakukan dengan berbagai metode penginduksian. Terdapat 12 penelitian mengenai aktivitas antidiabetes pada kulit jeruk yang akan menjadi pokok bahasan dan dideskripsikan pada tabel 1 .

Tabel 1. Dosis Efektif pada Uji Aktivitas Antidiabetik dari Beberapa Jenis Jeruk (Citrus sp.)

\begin{tabular}{|c|c|c|c|}
\hline Ekstrak & Dosis Efektif & Metode & Literatur \\
\hline $\begin{array}{l}\text { Kulit jeruk lemon } \\
\text { (Citrus limon }(L .))\end{array}$ & 328 mg/kgBB & Induksi Aloksan & (Neovita et al., 2021) \\
\hline $\begin{array}{l}\text { Kulit jeruk manis } \\
\text { (Citrus Sinensis) }\end{array}$ & $500 \mathrm{mg} / \mathrm{kgBB}$ & Induksi Aloksan & $\begin{array}{l}\text { (Muhtadi et al., } \\
\text { 2015) }\end{array}$ \\
\hline $\begin{array}{l}\text { Kulit jeruk manis } \\
\text { (Citrus Sinensis) }\end{array}$ & $150 \mathrm{mg} / \mathrm{kgBB}$ & $\begin{array}{l}\text { Zucker fatty rat } \\
(Z F R)\end{array}$ & (Gosslau et al., 2018) \\
\hline $\begin{array}{l}\text { Kulit jeruk manis } \\
\text { (Citrus Sinensis) }\end{array}$ & $10 \%$ & Induksi Aloksan & $\begin{array}{l}\text { (Hammad et al., } \\
\text { 2018) }\end{array}$ \\
\hline $\begin{array}{l}\text { Kulit jeruk sunkist } \\
\text { (Citrus Sinensis (L) }\end{array}$ & $100 \mathrm{mg} / \mathrm{kgBB}$ & $\begin{array}{l}\text { Induksi } \\
\text { Streptozotocin }\end{array}$ & (Ahmed et al., 2017) \\
\hline Osbeck) & & & \\
\hline $\begin{array}{l}\text { Jeruk Nipis (Citrus } \\
\text { aurantifolia) }\end{array}$ & $250 \mathrm{mg} / \mathrm{kgBB}$ & Induksi Aloksan & $\begin{array}{l}\text { (Serang \& Bani, } \\
\text { 2017) }\end{array}$ \\
\hline $\begin{array}{l}\text { Kulit jeruk sunkist } \\
\text { (Citrus sinensis } \quad \text { (L.) }\end{array}$ & $1000 \mathrm{mg} / \mathrm{kgBB}$ & $\begin{array}{l}\text { Induksi } \\
\text { Streptozotocin }\end{array}$ & (Depari et al., 2021) \\
\hline Osbeck) & & & \\
\hline
\end{tabular}




\begin{tabular}{lllll}
\hline Kulit jeruk nipis $500 \mathrm{mg} / \mathrm{kg} \mathrm{BB}$ & Induksi aloksan & (Ulfa et al., 2020)
\end{tabular}

(Citrus aurantifolia)

Kulit jeruk lemon $70 \mathrm{mg} / \mathrm{kgBB}$ Zucker fatty rat (Hartanto et al., (Citrus limon (L.)) $(Z F R)$

Kulit Jeruk Keprok $100 \mathrm{mg} / \mathrm{kgBB} \quad$ Induksi (Ali et al., 2020)

(Citrus Reticulata) Streptozotocin

Kulit jeruk manis $100 \mathrm{mg} / \mathrm{kgBB}$ Induksi aloksan

(Rohmah, 2019)

(Citrus sinensis)

Kulit jeruk manis 9\%

Induksi STZ

(Cahya, 2016)

(Citrus Aurantium L.)

Kulit jeruk manis 100mg/kgBB Induksi aloksan (Sovia, 2021)

(Citrus sinensis)

Neovita et al. (2021) telah melakukan
penelitian selama 2-3 minggu. Dengan metode Induksi Aloksan yang dilakukan secara intra peritoneal (IP) 175 $\mathrm{mg} / \mathrm{kgBB}$. Kemudian diamati kadar gula darah tikus 1-2 minggu. Ekstrak etanol kulit jeruk lemon (Citrus limon (L.)) dinyatakan berpotensi sebagai antidiabetes oral karena menunjukkan hasil berbeda bermakna dengan kontrol positif $(\mathrm{p}<0,05)$ dan setara dengan glibenklamid $(\mathrm{p}>0,05)$. Dosis 328 $\mathrm{mg} / \mathrm{kgBB}$ merupakan dosis efektif untuk menghambat peningkatan kadar gula darah tikus jantan diabetes SpragueDawley (Neovita et al., 2021).

Muhtadi et al. (2015) Melakukan penelitian terhadap aktivitas antidiabetes dan anti hiperkolesterolemia kulit jeruk manis (Citrus Sinensis) pada tikus. Dosis aloksan monohidrat $150 \mathrm{mg} / \mathrm{kg}$ diberikan secara intraperitoneal, yang mampu menginduksi kondisi diabetes

pada tikus. Induksi aloksan
menyebabkan peningkatan kadar glukosa darah menjadi $\pm 200 \mathrm{mg} / \mathrm{dL}$, yang dianggap sebagai tikus diabetes. Hasilnya menunjukkan bahwa dosis ekstrak kulit buah jeruk yang lebih tinggi menunjukkan penurunan kadar darah yang lebih besar. Dosis tertinggi ekstrak kulit buah jeruk adalah 500 $\mathrm{mg} / \mathrm{kgBB}$ menunjukkan penurunan sebesar $61,36 \% \pm 5,57 \%$ kadar glukosa darah bila dibandingkan dengan dosis terendah yaitu $125 \mathrm{mg} / \mathrm{kg}$ BB yang menunjukkan penurunan sebesar $39,24 \% \pm 4,96 \%$ yang merupakan penurunan kadar glukosa darah terendah (Muhtadi et al., 2015).

Gosslau et al. (2018) melakukan penelitian yang menguji efek esktrak kulit jeruk manis (Citrus Sinensis) pada tikus Zucker atau Zucker fatty rat (ZFR) yang mana model tikus dikenal tikus yang obesitas secara genetik. Dosis 
ekstrak yang digunakan dalam penelitian ini adalah $75 \mathrm{mg} / \mathrm{kgBB}$ dan $150 \mathrm{mg} / \mathrm{kgBB}$. Hasil menunjukkan pada kelompok kontrol tidak menunjukkan perubahan besar terhadap penurunan glukosa selama penelitian. Namun pada kelompok konsentrasi ekstrak kulit jeruk yang tinggi $(150 \mathrm{mg} / \mathrm{kgBB})$ terjadi penurunan glukosa puasa yang paling besar dan signifikan dengan nilai $(\mathrm{P}<0,05)$ (Gosslau et al., 2018).

Hammad et al. (2018) telah melakukan penelitian terhadap kelompok tikus yang diberi pakan diet kulit jeruk selama 28 hari dengan tingkat yang berbeda yaitu $5 \%, 7,5 \%$, dan $10 \%$. Induksi diabetes pada tikus jantan dengan injeksi aloksan 150mg/kgBB secara intra peritoneal. Ekstrak kulit jeruk dapat memberikan manfaat bagi penderita diabetes dan dapat mengurangi makan yang berlebihan. Hal ini disebabkan serat alami dalam kulit jeruk sebagai sumber alami pektin yang membantu dalm mengurangi kadar gula darah. Data yang didapatkan dalam penelitian ini pengurangan kadar gula darah tertinggi tercapai pada kelompok tikus diabetes yang diberi makan 10\% kulit jeruk (Hammad et al., 2018).

Ahmed et al. (2017) melakukan penelitian pada tikus diabetes yang di injeksi streptozotocin $50 \mathrm{mg} / \mathrm{kgBB}$ secara intraperitoneal. Lalu tikus diobati secara oral dengan esktrak kulit jeruk sunkist (Citrus Sinensis (L) Osbeck, naringin, dan narengenin selama 4 minggu. Hasil penelitian menunjukkan pada kelompok ekstrak kulit jeruk sunkist dosis $100 \mathrm{mg} / \mathrm{kgBB}$ memiliki potensi sebagai antidiabetik. Efek ini dimediasi melalui peningkatan respon sekresi insulin dan sensitivitas insulin. Peningkatan ekspresi reseptor insulin memiliki peran penting dalam meningkatkan sensitivitas insulin sebagai hasil pengobatan (Ahmed et al., 2017).

Serang dan Bani (2017) melaporkan bahwa kadar glukosa darah tikus setelah diberikan sediaan uji selama 24 hari (T3) menunjukkan bahwa kelompok kontrol positif glibenklamid $0,45 \mathrm{mg} / \mathrm{kg}$ BB tikus memiliki nilai rata-rata penurunan kadar glukosa darah tertinggi, artinya kelompok kontrol positif memiliki aktivi- tas yang lebih tinggi terhadap penurunan kadar glukosa darah tikus, diikuti kelompok ekstrak eta- nol daun jeruk nipis $250 \mathrm{mg} / \mathrm{kg}$ BB tikus, kelom- pok ekstrak etanol daun jeruk nipis $125 \mathrm{mg} / \mathrm{kg}$ BB tikus, kelompok ekstrak etanol daun jeruk nipis $62,5 \mathrm{mg} / \mathrm{kg}$ BB tikus dan yang terendah ada- lah kelompok kontrol negatif CMC 0,5\%. Bahwa kelompok ekstrak etanol daun jeruk nipis 250 $\mathrm{mg} / \mathrm{kg}$ BB tikus memiliki aktifitas yang paling baik dalam menurunkan kadar glukosa darah, walaupun belum se- 
banding dengan kelompok kontrol positif (Serang \& Bani, 2017).

Depari et al. (2021) melaporkan hasil uji kruskal-wallis profil lipid tidak didapatkan perbedaan yang signifikan pada pre dan post induksi STZ ( $p>0,05)$. Namun didapatkan penurunan kadar profil lipid pada kelompok standard dan kelompok ekstrak. Penurunan kadar TC, TGA, dan LDL terbanyak adalah pada kelompok P3 dengan dosis ekstrak 1000 $\mathrm{mg} / \mathrm{kgBB}$. Hasil uji menggunakan mann-whitney juga menunjukkan bahwa terdapat perbedaan nyata kadar TC. TGA dan LDL antara kelompok standar dan perlakuan dengan kelompok kontrol. Hasil penelitian ini sejalan dengan penelitian Rajiv dan kawankawan dimana pemberian ekstrak kulit jeruk Sunkist (50 dan $100 \mathrm{mg} / \mathrm{kg}$ ) serta metformin dapat menurunkan kadar, TC, TGA, LDL dibandingkan dengan kelompok kontrol (Depari et al., 2021).

Pemberian ekstrak kulit jeruk nipis selama 15 hari dengan dosis $250 \mathrm{mg} / \mathrm{kg}$ $\mathrm{BB}, 375 \mathrm{mg} / \mathrm{kg}$ BB dan $500 \mathrm{mg} / \mathrm{kg}$ BB memperlihatkan penurunan kadar glukosa darah adanya perbedaan yang bermakna secara statistik $(\mathrm{p} \leq 0,05)$ terhadap kontrol negatif. Ekstrak kulit jeruk nipis dengan dosis tertinggi yaitu $500 \mathrm{mg} / \mathrm{kg}$ BB merupakan dosis yang lebih efektif dalam menurunkan kadar glukosa darah jika dibandingkan dengan dosis $250 \mathrm{mg} / \mathrm{kg}$ BB dan $375 \mathrm{mg} / \mathrm{kg}$ BB (Ulfa et al., 2020).

Hartanto et al. (2019) juga melaporkan bahwa penurunan kadar kolesterol darah yang bervariasi sehingga memberikan standar deviasi yang cukup besar. Dilihat secara umum kelompok uji menunjukan adanya penurunan kadar kolesterol pada minggu ke-3 yang di bandingkan dengan awal penelitian, bedasarkan data pada kelompok kontrol positif, hewan uji menujukan keadaan hiper kolesterol hingga minggu ke 6. Ekstrak etanol kulit lemon berpotensi untuk menghambat peningkatan kadar kolesterol pada tikus hiperglikemia. Ekstrak etanol kulit lemon dosis $70 \mathrm{mg} / \mathrm{kg}$ bb/hari memiliki potensi terbaik dalam menurunkan kadar kolesterol total pada tikus hiperglikemia (Hartanto et al., 2019).

Sementara itu, Ali et al. (2020) menunjukkan bahwa hewan normal memiliki kadar glukosa serum puasa yang secara signifikan lebih rendah daripada hewan diabetes. Kadar glukosa serum mencapai nilai puncaknya setelah 60 menit setelah asupan glukosa $(3 \mathrm{~g} / \mathrm{kg}$ bb) dan mulai menurun selama 60 menit berikutnya untuk mencapai tingkat minimum pada 2 jam pemberian glukosa oral. Di sisi lain, kadar glukosa serum tikus kontrol diabetes NA/STZ juga mencapai maksimum setelah 60 menit pemberian glukosa oral. Kemudian, nilai 
ini mulai menurun tetapi dalam tingkat yang lebih lambat dan masih lebih tinggi dibandingkan dengan nilai normal. Selanjutnya, tikus kontrol diabetes menunjukkan peningkatan yang sangat signifikan dalam kadar glukosa serum ( $p$ $<0,01$; LSD) dibandingkan dengan yang normal di semua titik OGTT. Setelah 4 minggu pengobatan, Pengobatan Oksidatif dan Umur Panjang Seluler (Ali et al., 2020).

Rohmah et al. (2019) menunjukkan bahwa berdasarkan uji Post Hoc Tukey menunjukkan bahwa antara kelompok I dengan kelompok III dan IV memiliki nilai $P$ yang tidak signifikan $(p>0,05)$, hal ini berarti kadar glukosa darah pada kelompok III dan IV sudah mencapai kadar normal pada hari ke 12 setelah perlakuan karena tidak memiliki perbedaan bermakna dengan kelompok I sebagai kontrol negatif yang memiliki kadar glukosa darah normal (Rohmah, 2019).

Terakhir, Sovia (2021) juga melaporkan bahwa pada akhir masa penelitian (setelah 12 hari pengobatan), hewan diabetes pada kelompok perlakuan menunjukkan penurunan kadar glukosa darah yang sangat signifikan $(\mathrm{p}<0,01)$. Kadar glukosa darah akhir pada kelompok perlakuan kombinasi B $(109,79 \pm 59,69 \mathrm{mg} / \mathrm{dl})$ lebih rendah dibandingkan kombinasi A
$(111,17 \pm 21,86 \mathrm{mg} / \mathrm{dl})$, namun tidak berbeda nyata $(\mathrm{p}=0,999)$ (Sovia, 2021).

\section{KESIMPULAN DAN SARAN}

\section{Kesimpulan}

Dari 12 penelitian yang direview dapat disimpulkan bahwa kulit jeruk memiliki aktifitas antidiabetes dengan penurunan kadar gula darah pada hewan uji yang telah diberikan ekstrak kulit jeruk dengan dosis efektif pada masingmasing penelitian yang telah direview.

\section{Saran}

Diharapkan untuk penelitian selanjutnya agar memperbanyak penelitian penggunaan antidiabetic dengan kulit jeruk sebagai pilihan terapi, khususnya pada penyakit diabetes mellitus.

\section{DAFTAR PUSTAKA}

Ahmed, O. M., Hassan, M. A., AbdelTwab, S. M., \& Abdel Azeem, M. N. (2017). Navel orange peel hydroethanolic extract, naringin and naringenin have antidiabetic potentials in type 2 diabetic rats. Biomedicine and Pharmacotherapy, 94(October), 197-205.

https://doi.org/10.1016/j.biopha. 2017.07.094

Ali, A. M., Gabbar, M. A., Abdel-Twab, S. M., Fahmy, E. M., Ebaid, H., Alhazza, I. M., \& Ahmed, O. M. (2020). Antidiabetic Potency, Antioxidant Effects, and Mode of Actions of Citrus reticulata Fruit Peel Hydroethanolic Extract, Hesperidin, and Quercetin in Nicotinamide/StreptozotocinInduced Wistar Diabetic Rats. 
Oxidative Medicine and Cellular Longevity, 2020. https://doi.org/10.1155/2020/17 30492

Cahya, B. T. (2016). carbon emission disclosure: ditinjau dari Media exposure, kinerja lingkungan dan karakteristik perusahaan. 39-37, 66, עלון הנוטע.

Depari, S. A. F., Jihan, D., Rambe, A., Meilando, R., Lisya, C., Mutia, M. S., Eliza, Y., \& Lubis, P. (2021). Uji Efektivitas Ekstrak Etanol Kulit Jeruk Sunkist (Citrus Sinensis ( L .) Osbeck) Terhadap Kadar Gula Darah Tikus Wistar (Rattus Norvegicus) Dengan Hiperkolesterolemia. 14(1), 19.

Esmail Al-Snafi, A., Majid, W. J., Ali Talab, T., \& Al-Battat, H. A. (2019). Medicinal Plants with Antidiabetic Effects-An Overview (Part 1). IOSR Journal of Pharmacy, 9(3), 946. www.iosrphr.org

Gosslau, A., Zachariah, E., Li, S., \& Ho, C. T. (2018). Effects of a flavonoid-enriched orange peel extract against type 2 diabetes in the obese ZDF rat model. Food Science and Human Wellness, 7(4), 244-251. https://doi.org/10.1016/j.fshw.2 018.10 .001

Hammad, E., Kostandy, M., \& ElSabakhawi, D. (2018). Effect of feeding sweet orange peels on bloodglucose and lipid profile in Diabetic and hypercholesterolemic. Bulletin of the National Nutrition Institute of the Arab Republic of Egypt, 51(1), 70-90. https://doi.org/10.21608/bnni.20 18.14163

Handayani, F., \& Muhtadi, A. (2013). Aktivitas dan efektivitas antidiabetes pada beberapa tanaman herbal. Farmaka, 18(1), 1-15.
Hartanto, D. T., Kurniasari, E. L., Maria, R. A., Dewi, P. S., \& Septiani, V. (2019). Potensi Ekstrak Etanol Kulit Jeruk Lemon (Citrus limon L.) Sebagai Obat Alternatif Hiperkolesterolemia Pada Tikus Wistar Hiperglikemik. Kartika: Jurnal Ilmiah Farmasi, 6(2), 81-85.

https://doi.org/10.26874/kjif.v6i 2.156

Khairani, K. (2014). Pengetahuan Diabetes Mellitus Dan Upaya Pencegahan Pada Lansia Di Lam Bheu Aceh Besar. Idea Nursing Journal, 5(3), 58-66.

Kumar, P. R. Z. A., \& Bhaskar, A. (2015). Evaluation of antihyperglycaemic and antihyperlipidemic activity of Citrus sinensis peel extract on streptozotocin-induced diabetic rats. International Journal of Diabetes in Developing Countries, 35(4), 448-453. https://doi.org/10.1007/s13410015-0310-7

Luka, C., Istiganus, G., George, M., \& Philip, C. (2017). The Effect of Aqueous Extract of Citrus sinensis Peel on Some Biochemical Parameters in Normal and Alloxan-Induced Diabetic Wister Rats. American Journal of Phytomedicine and Clinical Therapeutics, 5(2), 1-8. https://doi.org/10.21767/23212748.100330

Muhtadi, Haryoto, Azizah, T., Suhendi, A., \& Yen, K. H. (2015). Antidiabetic and antihypercholesterolemic activities of Citrus sinensis peel: In vivo study. National Journal of Physiology, Pharmacy and Pharmacology, 5(5), 382-385. https://doi.org/10.5455/njppp.20 15.5.2807201561

Ndraha, S. (2014). Diabetes Melitus Tipe 2 Dan Tatalaksana Terkini. Medicinus, 27(2), 9-16. 
Neovita, E., Solihah, P. S. D., Wahyuningsih, S., Aeni, H. H., \& Azhari, F. (2021). Pengembangan Ekstrak Etanol Kulit Jeruk Lemon (Citrus limon (L.)) sebagai Antidiabetes Oral. Kartika: Jurnal Ilmiah Farmasi, $\quad 8(1), \quad 1$. https://doi.org/10.26874/kjif.v8i 1.220

Rohmah, A. S. (2019). Efek Antihiperglikemi Kombinasi Ekstrak Etanol Kulit Jeruk (Citrus sinensis) dan Ekstrak Etanol Kulit Buah Delima (Punica granatum L.). Universitas Jendral Achmad Yani Cimahi.

Serang, Y., \& Bani, F. (2017). Uji Aktivitas Anti-Hiperglikemik, dan Penghambatan Stres Oksidatif Ekstrak Etanol Daun Jeruk Nipis (Citrus aurantifolia) pada Tikus Diabetes yang Diinduksi Aloksan. Biomedika, 10(1), 85-92. https://doi.org/10.31001/biomed ika.v10i1.232

Sinata, N., \& Arifin, H. (2016). Antidiabetes dari Fraksi Air Daun Karamunting (Rhodomyrtus tomentosa (Ait.) Hassk.) Terhadap Kadar Glukosa Darah Mencit Diabetes. Jurnal Sains Farmasi \& Klinis, 3(1), 72. https://doi.org/10.29208/jsfk.20 16.3.1.102

Soelistijo, S. A., Novida, H., Rudijanto, A., Soewondo, P., Suastika, K., Manaf, A., Sanusi, H., Lindarto, D., Shahab, A., Pramono, B., Langi, Y. A., Purnamasari, D., Soetedjo, N. N., Saraswati, M. R., Dwipayana, M. P., Yuwono, A., Sasiarini, L., Sugiarto, Sucipto, K. W., \& Zufry, H. (2015). Konsensus Pengendalian dan Pencegahan Diabetes Melitus Tipe 2 di Indonesia 2015. In Perkeni. PB Perkeni.
https://doi.org/10.1017/CBO978 1107415324.004

Sovia, E. (2021). Effect of Sweet Orange and Pomegranate Peel Extract Combination on in Vivo Antidiabetic and Wound Healing Activity. 37(Asmc), 4953.

Sujana, D., Nurul, \& Ramdani, H. T. (2017). Aktivitas Antidiabetes dan Kandungan Senyawa Kimia dari Berbagai Bagian Tanaman Alpukat (Persea americana) "Jurnal Review". Neuropsychology, 3(8), 85-102. http://clpsy.journals.pnu.ac.ir/art icle_3887.html

Ulfa, A. M., Nofita, N., \& Bonita, B. N. (2020). Uji Aktivitas Penurunan Kadar Glukosa Darah Ekstrak Etanol Kulit Jeruk Nipis (Citrus aurantifolia) pada Tikus Jantan Spargue Dawley yang Diinduksi Aloksan. Jurnal Farmasi Malahayati (JFM), 3(2), 125136.

https://doi.org/https://doi.org/10. 33024/jfm.v3i2.3799

Yu, Y., Xie, R., Shen, C., \& Shu, L. (2018). Effect of exercise during pregnancy to prevent gestational diabetes mellitus: a systematic review and meta-analysis. Journal of Maternal-Fetal and Neonatal Medicine, 31(12), 1632-1637.

https://doi.org/10.1080/1476705 8.2017.1319929 